\title{
Escaping Violence, Seeking Freedom: Why Children In Bangladesh Migrate To The Street
}

\section{GPRG-WPS-047}

\section{Alessandro Conticini and David Hulme}

\section{Global Poverty Research Group}

Website: http://www.gprg.org/

The support of the Economic and Social Research Council (ESRC) is gratefully acknowledged. The work was part of the programme of the ESRC Global Poverty Research Group. 


\title{
ESCAPING VIOLENCE, SEEKING FREEDOM: \\ WHY CHILDREN IN BANGLADESH MIGRATE TO \\ THE STREET
}

\author{
Alessandro Conticini and David Hulme
}

(C) Alessandro Conticini and David Hulme September 2006

Contacts: conticini@hotmail.com

david.hulme@manchester.ac.uk 


\title{
ESCAPING VIOLENCE, SEEKING FREEDOM: WHY CHILDREN IN BANGLADESH MIGRATE TO THE STREET ${ }^{1}$
}

\begin{abstract}
In Bangladesh, as in many developing countries, there is a widespread belief amongst the public, policymakers and social workers that children 'abandon' their families and migrate to the street because of economic poverty. This dominant narrative posits that children whose basic material needs cannot be met within the household move to the street. It ignores and avoids the growing evidence that this is not the case. This paper explores this argument through the analysis of detailed empirical research with children in Bangladesh. It finds that social factors lie behind most street migration and, in particular, that moves to the street are closely associated with violence to, and abuse of, children within the household and local community. These findings are consistent with the wider literature on street migration from other countries. In Bangladesh, those who seek to reduce the flow of children to the streets need to focus on social policy, especially on how to reduce the excessive control and emotional, physical and sexual violence that occurs in some households. Economic growth and reductions in income poverty will be helpful, but they will not be sufficient to reduce street migration by children.
\end{abstract}

\footnotetext{
${ }^{1}$ This article has been prepared with funding received from the Economic and Social Research Council (ESRC) post-doctoral programme (award number PTA-026-27-0751) and the ESRC grant to the Global Poverty Research Group (GPRG). ESRC support is gratefully acknowledged. Our thanks to David Clark, Karen Moore and two anonymous referees for comments on earlier drafts of the paper. We are indebted to the children who participated in the study and taught us so much about life 'on the street'.
} 
'I did not leave home for poverty... when I say I'm on the street because my family was poor... [people] nod... and give me coins... if I say I'm on the street because my parents were violent, people blame me saying I was not a good boy' [Interview with Rocky, a 16 years old boy, 2002].

\section{INTRODUCTION}

Children living in street situations ${ }^{2}$ are an increasing phenomenon in developing countries (Panter-Brick, 2002; Pare, 2003) and economically advanced countries (Bradbury, Jenkins et al., 2000; Bustamante, 1999; Solito, 1994). Amongst the world's one billion children suffering from deprivation of basic needs (Gordon, Nandy et al., 2003), these children are highly likely to experience 'absolute poverty' (Bartlett, Hart et al., 1999). Once on the street their living experience can be viewed as a condition of both severe and chronic poverty. ${ }^{3}$ The plight of girls in street situations is a special concern (Barker and Knaul, 2000).

Many types of programme attempt to assist children in street situations - 'street children', 'hard to reach children', 'working children', 'children in need of special protection' or 'specially disadvantaged children'. However, their high spatial mobility, independence and suspicion of adults means that attempts to provide support and reintegration are problematic and often unsuccessful (Black, 1993; Blanc,

\footnotetext{
2 'Children in street situations' is a term which has been preferred to the commonly used expression 'street children'. There are a number of reasons for choosing the former expression. Arguably, when referring to children as 'street children', we implicitly associate the negative characteristics of the street environment with their childhood, conceptualising them as belonging to the street and assuming an approach which is both offensive (Dallape, 1996) and incomplete (Aptekar, 1988). Further, the 'street children' concept is a static definition unable to recognise the capacity of these children to move among different social environments (Lucchini, 1996a).
} 
1994). Commonly, policymakers and social activists have prioritized preventing or reducing child migration to the streets and this has led to a research focus on the causes of children leaving their families and moving to the streets.

This paper seeks to deepen our understanding of why children in Bangladesh 'move to the street'. According to a recent official study some 500,000 children are living on the streets in the country's main cities (ARISE, 2001). It frames this analysis within broader discourses concerning the nature of poverty. In particular, it distinguishes between economic (income/consumption) and other dimensions of poverty and uses both objective and subjective assessments of poverty. Underpinning the paper is a belief that development action is not simply about the provision of basic needs or minimum incomes but about raising people's (including children's) ability to access and convert livelihood assets (human, social, physical, natural and financial) into desired beings, doings and becomings. ${ }^{4}$

By adopting a more holistic and multidimensional view of poverty, and utilizing the findings of extended qualitative research methods, we argue that in Bangladesh children move to the street not simply because of economic (income, consumption or material) shortfalls as is commonly assumed. Rather, it is the abuse of human rights, especially in terms of physical violence, and the breakdown of trust within

\footnotetext{
${ }^{3}$ For a discussion of the concepts of severe and chronic poverty and their relationships see Hulme and Shepherd (2003), Hulme, Shepherd and Moore (2001) and Yaqub (2003).

${ }^{4}$ Amartya Sen's (1999) work has helped analysts to appreciate the importance of 'beings' and 'doings'. However, lives, welfare and poverty are dynamic and so it is also important to understand human action in terms of the future it seeks, through 'becomings' (we are indebted to Flavio Comin for a discussion concerning how to make Sen's ideas more dynamic). For discussions of livelihood analysis see Chambers and Conway (1992), Ellis (1998) and Scoones (1998).
} 
households ${ }^{5}$ that leads children to move to the street. This is very much in line with earlier groundbreaking work on the subject (i.e. Aptekar, 1988) and stresses the need to better understand the magnitude, incidence and consequences of domestic violence against children. ${ }^{6}$

The perception of street living children held by the general public, policy makers and many social scientists in Bangladesh is filtered through, and conditioned by, a 'dominant narrative' (Roe, 1999) which posits that children are on the street because their parents or guardians cannot meet the household's basic material needs. The role played by violence within the household and the strength of the social bonds built by children on the street are too often ignored by commentators on this 'problem' in Bangladesh. This analysis indicates that policies and actions to reduce street migration by children in the country will need to drop the assumption that material poverty is the main cause and tackle the more contentious issues of emotional, physical and sexual violence.

\section{AN OVERVIEW OF THE CAUSES OF STREET MIGRATION}

Until recently, many studies have identified economic poverty as the main, and sometimes the only, cause leading children in developing countries to migrate to the street (Alexandrescu, 1996; Peacock, 1994; Scheper-Hughes and Hoffman, 1998). Economic poverty has been presented both as a direct and indirect factor that 'pushes' children onto the street. It is argued that children move out of the household as a direct coping strategy, to diversify the household's portfolio of income generating

\footnotetext{
5 The concept of household is preferred here to the one of family because it is broader and more dynamic.
} 
activities, and that, at the same time, economic poverty leads to stresses and tensions within the household, that become an indirect cause of street migration ${ }^{7}$ (CSC, 2001). Indeed, UNICEF (2002) has declared the failure to reduce income inequality among and within households as a missed opportunity for tackling the causes of poverty and street migration for children.

Such arguments have been taken up very strongly in Bangladesh where most studies see economic poverty and/or economic shocks (such as land erosion, floods, financial shocks and especially the shortage of food) as the main reason why children move to the street (Ahmed and Adeeb, 1998; ARISE, 2001; BSAF, 1998). Low incomes in rural areas, it is argued, compel children to migrate to urban centers to mitigate their material hardships and contribute to household earnings. Hasina (1989) postulates that in rural areas household food insecurity leads to elder children abandoning the household. Indeed, economic factors are seen as the driving force behind street migration, and 'the influx of migration could be stopped... only through massive economic poverty alleviation interventions' (ARISE, 2001). Even if reasons other than material poverty are quoted, economic deprivation remains the primary focus for intervention (White, 2002), and the non-material elements necessary for a

\footnotetext{
${ }^{6}$ In doing so, the paper contributes and refers to the ongoing UN Secretary-General's Study on Violence Against Children that should lead to the development of strategies aimed at effectively preventing and combating all forms of violence against children (E/CN.4/2004/68).

${ }^{7}$ In specific countries causes other than economic poverty play a leading role. In African countries with high rates of HIV/AIDS infection many orphans move to the street as a consequence of having no other place to go. In post conflict areas, a high number of children in street situations are displaced from their household, get lost or are orphaned by war. These are indeed causes not directly related with the macro economic structure of the country but with contingent shocks and fragile political situations. It should also be noted, however, that in such contexts (high rates of HIV/AIDS, conflict zones) violence against children is often at high levels.
} 
holistic vision of child poverty (Minujin, Vandemoortele et al., 2002) are not recognized as a priority for policy and action.

We argue here that economic conditions and shocks are only a limited part of the explanation for migration to city streets by children and that analysts and policy makers have so far missed the opportunity of significantly engaging with a growing body of literature that shows the decisive role played by non economic factors in children's decision to migrate to the street.

According to Moser (1998), capturing the multidimensional aspects of the changing socio-economic well-being of poor people including children, requires the recognition of empowerment processes. From the empirical literature on the topic, key researchers can be identified who have argued for less economistic analyses and for a deeper examination of family life. In particular, Felsman (1989) found that 97 per cent of his sample of Colombian children in street situations had actively abandoned their households due to a non-conducive family environment. Further, street life helped in the development of children's resilience and street living children had better mental health than their counterparts in families. Aptekar (1988) found that children in street situations were emotionally intact in their intellectual functioning, and achieved high levels of self-management. Veale (1992) compared children in street situations in Sudan and Ireland, considering their different backgrounds, socialdemographic characteristics and the processes of their street life involvement. In both cases, she found that street life was a rational choice when considering alternative options and risks. De Oliveira, Baizerman et al. (1992) showed that 65 per cent of Brazilian children in street situations defined themselves as 'good persons' with 
positive aspirations for the future. Furthermore, Monteiro, Campos et al. (1998) have found that children in street situations develop strong characteristics of initiative and positive identity while Lugalla and Mbwambo (1999) found that Tanzanian street living children are highly organised in groups of peers who share resources, strategies, assets and care. Chawla (2002) reports that the interaction of children in street situations, within neighbourhoods and street communities, is the keystone for understanding the growth of impressive ethical behaviours and that street life fosters the development of 'cultural richness'. According to Baker (2000), the street network of friendships can reduce the real and perceived feeling of vulnerability and social exclusion, and raise the well-being of children in street situations. This is achieved mainly through the development of a 'collective identity' and 'feeling of belonging' that give the child the opportunity to be an active player within this urban sub-culture (Lucchini, 1996a).

These empirical studies reveal the importance of non-economic factors in children's decisions to migrate and stay on the streets and indicate that street life not only involves vulnerability processes but also processes of empowerment through which children exercise their personal agency and develop innovative coping behaviours.

In consequence, reducing economic poverty is, at best, only a partial solution to the problem of 'run away' children. Low income and material poverty can lead some children onto the street, but it usually will not break household ties (Blanc, 1994). In such circumstances children should be considered as members of a 'multi-spatial household' (Tacoli, 1999) with 'mobile livelihoods' (Olwig and Sørensen, 2001; Stepputat and Sørensen, 2001). Such children regularly return to their household to 
share income and maintain social relationships. In the Bangladesh context, they do not define themselves as tokai (children in street situations) because their assets and affections are still shared with other household members.

While the process of street migration involves the interaction of both 'push' and 'pull' factors, the analysis that follows focuses on 'push' factors. This is because the emotional bond between children and parents or guardians and other household members can only be broken if the adult-child relation collapses (Veale, 1992). In other words, children tend to maintain and protect the 'natural' status of being under the supervision of adults (usually parents) unless push factors weaken or damage the relationship (Masud Ali, Mustaque Ali et al., 1997), leading to the breaking of household ties. The parallel feeling of empowerment and freedom experienced when running away makes street life attractive. Issues such as the social bonding that children experience on the street, the formation of urban sub-cultures, the evolution of their self-perception are of significance in understanding the attachment that children develop to the street and the difficulties they face in reintegrating into their former households. These complex interactions of push and pull factors can keep or even entrap children on the street. But to a large extent they are subordinate to the initial breakdown of household ties which, makes these 'pull' factors of prime importance in understanding why migration occurs. Overall, the stress of economic poverty serves as a push factor, making migration more likely in Bangladesh, but we argue it plays a secondary role in comparison to the role that social relationships play in the family and on the street. 


\section{METHODOLOGY AND METHODS ${ }^{8}$}

As previous studies have demonstrated, the research methods commonly used to investigate children in street situations can lead to inaccurate data and unreliable conclusions (Connolly and Ennew, 1996; Ennew and Milne, 1996; Lucchini, 1996b; Panter-Brick and Smith, 2000). Until recently, studies on migration processes have tended to focus on quantitative, survey data collection and interpretation rather than on the experiences of those involved in the migratory process (Zhang, 1999). In particular, when investigating children in street situations, conventional survey-based quantitative approaches do not seem suitable because they are unable to create a trust relationship between the interviewer and child. This is an important constraint, especially given the suspicion children in street situations commonly have for adults. As a result, qualitative research methods should take priority.

This study draws on field research conducted in Dhaka from August 2002 to July 2003 with 93 children in street situations. This involved 62 boys and 31 girls, with estimated $^{9}$ ages ranging from four to eighteen years. Most of these children were not involved in any 'street children programmes' at the time of the research, but a majority (65 percent) had been enrolled in NGO programmes at some earlier time. The main methods used were participant observation, play activities, in-depth

\footnotetext{
${ }^{8}$ The methodology for this study, and the methods used, were constantly developed and revised as research progressed to obtain more accurate data and to ensure that ethical standards were maintained. For a full discussion of these issues see Conticini (2004).

${ }^{9}$ A birth registration system has only recently been systematically introduced in Bangladesh and many children could only give an approximate age. The age given by children was accepted even when it was a clear under/over estimation compared with their physical development. This reflects the Bangladeshi practice of reporting age according to experiences more than physical development (Blanchet, 1996).
} 
interviews and group discussions. Moreover, eight boys and eight girls volunteered as members for two advisory groups responsible for reviewing all parts of the field research, undertaking some of the interviews, facilitating group discussions and suggesting changes in the research process. A child in a street situation was defined as a child ${ }^{10}$ who provides for his/her daily basic needs without the support of the household or other guardians, and who actively finds on the street his/her main caregivers.

Towards the end of field research, a semi-structured questionnaire was utilized to triangulate the qualitative data that had been collected and to add a quantitative dimension to the analysis. Eighty children participated in the semi-structured questionnaires, 37 were boys and 43 were girls. ${ }^{11}$ Nearly all children involved in the questionnaire had migrated to the city's street alone or with friends and the majority of them had already participated in earlier phases of the research. ${ }^{12}$ This meant there was usually a pre-existing trust relationship between the interviewer and children, making data more reliable than that collected through a one off questionnaire (Ennew and Milne, 1996).

While the focus of the research was Dhaka city, involving four sites frequented by children in street situations (a market, train and bus stations and a river port), some

\footnotetext{
${ }^{10}$ Although the Convention on the Rights of the Child (CRC) defines a child as every human being below the age of 18 years, it also recognises the possibility to attain earlier majority according to a country's law. Bangladeshi Laws apply manifold and inconsistent definitions of a child which contradict one another according to the Constitutional Provisions Relevant for Children Rights and the Laws Related to Children Rights. The legal system of the country also makes a gender distinction in defining a child, fixing a majority age for marriage at 18 for girls and 21 for boys (see the Child Marriage Restraint Act, 1929 amended in 1984).

${ }^{11}$ Two of the biological males referred to themselves as females and they were included in the 'girls' data.
} 
rapid field work was also undertaken in the cities of Chittagong, Rajshahi, Khulna, Gaibandha and Bogra, to check the relevance of data collected in Dhaka to other cities and to gain a broader picture of the nature of child migration. The timing of research was 'around the clock' including both day-time and night-time working children and seeking to capture data about all of their activities and relationships.

The main methodological constraint encountered was the impossibility of adopting sampling procedures to ensure that the relatively small group of interviewees represented the composition of the larger population of children in street situations in Dhaka. The exact or even the approximate characteristics (gender, age, area of origin) of the reference population are unknown, as is common for such studies (Connolly and Ennew, 1996; Ennew and Milne, 1996).

A number of key stakeholders working at different levels with children in street situations were also interviewed as well as 30 families in the village of Kutipara, Gaibandha District. This rural site was selected because Gaibandha is one of the poorest districts in Bangladesh in terms of income (Sen, 2000). It provided an opportunity to investigate the reasons that adults and children in the village believed had led to some children leaving their households to migrate to the street while others had not.

\section{ECONOMIC POVERTY AND STREET MIGRATION}

\footnotetext{
${ }^{12}$ A small number of new respondent girls were included to help deepen the understanding of gender differences.
} 
Our main finding is that the breakdown of social relationships within the household and not economic poverty is the main cause of child migration to the street. For children, the feeling of insecurity they experience before migrating to the street is central and not confined to the economic sphere of their life (see also Bruijn and Van Dijk, 1999). There are several arguments showing that the role of economic factors in child migration in Bangladesh, and elsewhere is exaggerated. First, if income/consumption poverty drove children to the street one would expect many more millions of children to be living on the pavements. The number of children living on the street is only a tiny proportion of total children living below the poverty line in Bangladesh. This implies, that economic poverty alone cannot explain why some children have abandoned their families and others have not.

Second, not all off the children living on the street are from economically poor households (Table 1). When considering the per capita expenditure of households, ${ }^{13}$ children living on the street have a variety of economic backgrounds ranging from severely poor households to well-off households. ${ }^{14}$ Only 48 percent of children interviewed were from poor and severely poor households. 26 percent and 16 percent respectively were from borderline and non-poor households.

\footnotetext{
${ }^{13}$ The children in street situations reported: (1) an estimate of the monthly income of the household at the time they left home, according to the wages of the different income providers; (2) how many people were living within the household; and (3) which year they left home. They also reported how many meals they used to have at home, if they had electricity, radio and TV, what kind of job the income providers were doing, seasonality of the jobs, ownership of land and animals and a description of their household furniture.

${ }^{14}$ In our study the household per capita poverty line was defined as the daily expenditure needed to ensure a minimum consumption of $2112 \mathrm{Kcal}$. for a person with normal dietary patterns, integrated with a monthly basic non-food expenditure component. The severe poverty line has been calculated as the daily expenditure needed to ensure a minimum consumption of $1950 \mathrm{Kcal}$. per person per day. Vulnerable households were defined as those with a per capita expenditure that was above the poverty line by no more than 30 per cent (see Sen, 2000, for further details).
} 
The Poverty Status of Children in Street Situations Households (per capita expenditure)

\begin{tabular}{lccccc}
\multicolumn{5}{c}{$\mathrm{N}=80$} \\
& $\begin{array}{c}\text { Severely Poor } \\
\text { Households } \\
\text { (Up to 1950 } \\
\text { Kcal. per day) }\end{array}$ & $\begin{array}{c}\text { Households } \\
\text { (between } \\
1950 \text { Kcal. } \\
\text { and 2112 } \\
\text { Kcal. per } \\
\text { day) }\end{array}$ & $\begin{array}{c}\text { Borderline } \\
\text { Households } \\
\text { (between } \\
2112 \text { and } \\
2745 \text { Kcal. } \\
\text { Per day) }\end{array}$ & $\begin{array}{c}\text { Non-poor } \\
\text { Households } \\
\text { (More than } \\
2745 \text { Kcal. } \\
\text { per day) }\end{array}$ & Don't Know \\
\hline $\begin{array}{l}\text { Respondents } \\
\text { Boys }\end{array}$ & $27 \%$ & $30 \%$ & $22 \%$ & $12 \%$ & $9 \%$ \\
$\begin{array}{l}\text { Respondents } \\
\text { Girls }\end{array}$ & $15 \%$ & $24 \%$ & $31 \%$ & $20 \%$ & $10 \%$ \\
\hline $\begin{array}{l}\text { Respondents } \\
\text { Total }\end{array}$ & $21 \%$ & $27 \%$ & $26.5 \%$ & $16 \%$ & $9.5 \%$
\end{tabular}

Note: In the Bangladeshi context, the poverty line is usually set at $2112 \mathrm{Kcal}$. per adult per day. There are several methods for setting the poverty line. Of these, the approach based on costing of a given food bundle (corresponding to $2112 \mathrm{Kcal}$. per person per day), the so called 'fixed bundle approach', is found to be better than other methods such as Food-Energy Intake (FFI). For details see Ravallion and Sen (1996).

Source: Conticini (2004).

The results attained by this method were corroborated by Sen and Begum's (2004) methodology for identifying the extreme poor, poor and non poor in rural Bangladesh. Children's households were ranked in terms of two qualitative indicators: the occupation of the main income provider and the quality of housing. According to Sen and Begum, the percentage of households in extreme poverty is highest for agricultural wage labourers, fishermen and non-agricultural labourers. Progressively better conditions are observed for petty traders, industrial workers, tenant farmers, owner farmers and formal sector employed or service holders. Housing is another indicator that strongly reflects the economic status of the household. Housing can be ranked as jhupri (made of discarded material such as plastic), thatch (made of natural material such as bamboo), tin (made from corrugated 
metal sheets) and pucca (built with permanent materials such as cement or brick). Table 2 presents the survey data about these factors at the time that children moved to the streets and identifies their poverty status by Sen and Begum's (2004) criteria.

Table 2

The Poverty Status of Children in Street Situations as assessed by Parental Occupation and Housing Quality

\begin{tabular}{|c|c|c|c|c|c|}
\hline & Jhupri & $\begin{array}{l}\text { One } \\
\text { Room } \\
\text { Thatch }\end{array}$ & $\begin{array}{l}\text { One+ } \\
\text { Room } \\
\text { Thatch }\end{array}$ & Tin House & $\begin{array}{l}\text { Pucca } \\
\text { House }\end{array}$ \\
\hline $\begin{array}{l}\text { Agricultural wage laborers } \\
\text { and fishermen }\end{array}$ & $9 \%$ & $5 \%$ & $2 \%$ & $1 \%$ & $0 \%$ \\
\hline Nonagricultural laborers & $2 \%$ & $7 \%$ & $8 \%$ & $0 \%$ & $1 \%$ \\
\hline Petty traders & $0 \%$ & $10 \%$ & $10 \%$ & $6 \%$ & $2 \%$ \\
\hline $\begin{array}{l}\text { Industrial workers/ owner } \\
\text { farmers }\end{array}$ & $0 \%$ & $2 \%$ & $10 \%$ & $9 \%$ & $2 \%$ \\
\hline $\begin{array}{l}\text { Tenant/ Formal sector } \\
\text { employed or service } \\
\text { holders. }\end{array}$ & $0 \%$ & $0 \%$ & $2 \%$ & $5 \%$ & $4 \%$ \\
\hline
\end{tabular}

Don't Know $=3 \%$

\begin{tabular}{|c|c|c|c|}
\hline $\begin{array}{c}\text { Households likely } \\
\text { to be classified as } \\
\text { extremely poor }\end{array}$ & $\begin{array}{c}\text { Households likely } \\
\text { to be classified as } \\
\text { poor }\end{array}$ & $\begin{array}{c}\text { Households likely } \\
\text { to be classified as } \\
\text { borderline }\end{array}$ & $\begin{array}{c}\text { Households likely } \\
\text { to be classified as } \\
\text { nonpoor }\end{array}$ \\
\hline
\end{tabular}

Source: Conticini (2004)

Households classified as extremely poor live in jhupri or one room thatch and have a main income provider who is an agricultural wage labourer, fisherman or nonagricultural labourer. Twenty three percent of children interviewed come from households with these characteristics. A further 30 percent of children come from households classified as poor. Importantly, a significant minority of children do not come from extreme poor or poor households. Twenty eight percent and 16 percent of children were respectively from borderline and non-poor households. Both methods indicate that a significant minority of children on the street do not come from 
households that can be considered poor in economic terms. This implies that economic poverty, in many cases, is not the main factor in explaining why children migrate to the street.

If economic factors were the prime reason for street migration, one would expect to observe a higher number of children coming from districts considered economically disadvantaged. However, there is no significant association between the mobility rank (MR), which indicates the districts from which our sample of children originate, and the ranking of Bangladeshi districts according to Sen's (2000) Income Poverty Index (IPI) (Table 3). The majority of children interviewed living on the street come from the districts of Barisal, Comilla and Dhaka, which have only low or moderate IPI ranks. If economic poverty were the main factor behind street migration one would expect a more significant overlap between being a child in street situation and coming from the poorest districts. ${ }^{15}$

\footnotetext{
${ }^{15}$ However, it must be observed that 'proximity' to cities can facilitate a child's initial migration to the street given the comparatively easier access to transport. This is the case for children migrating from the district of Dhaka to the city of Dhaka.
} 


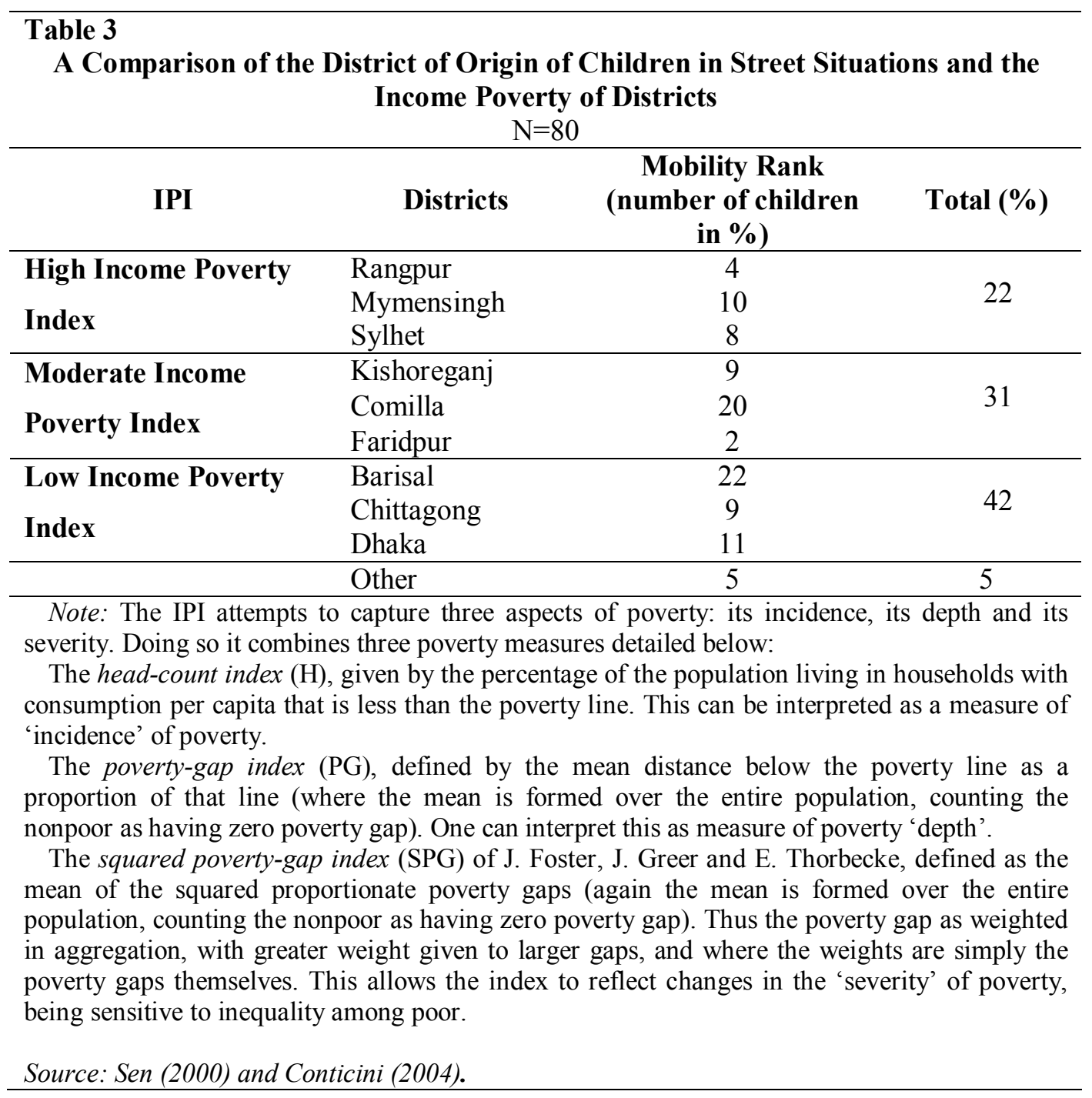

Fourth, if material poverty and economic hardship were the main causes of street migration, one would expect children to move to situations where they can most rapidly improve their economic position and security, while most children reported that the street was an economic environment that satisfied their basic needs, they also reported that it was not the best economic environment they could have chosen. As explained by Shumon ${ }^{16}$ (14 year old boy), a newcomer to the street:

${ }^{16}$ The names of children are disguised to protect their identity and ensure confidentiality. 
'Once I left home I could have gone to stay with my uncle and live with him because he has a big house and a good job. However, life with him would not have been so different from the life I wanted to quit. I did not trust adults any more and I did not want to be beaten by them for no reasons. Here in Dhaka I could have gone to a relative's house but I preferred freedom, living with friends on the street... The street gives me enough dal (lentils) to survive but I could have had more living facilities with my relatives, but what I seek now is to enjoy life with my friends and have security'.

Arguably, once they have left home, children pay at least as much attention, and probably more, to the development of social relationships as they do to economic opportunities. In turn, supportive social networks can improve (in most cases unintentionally) children's access to better economic opportunities in the future. They constantly seek to reduce their emotional vulnerability by developing social connections and friendships, rather than pursuing purely economic opportunities. In addition, as reported by social workers, even when the drop in centers for children in street situations provide them with food, shelter and a basic income, many children 'run away' and return to the street. Arguably, children who stay at drop in centers are those who have found protective security through building social relationships at the centers. As indicated, the basic needs satisfaction provided by formal institutions or foster care, do not stop children from returning to the street. Once survival and basic earnings are secured, children in street situations choose their living environment in terms of trust relations and physical/emotional security rather than economic factors. 
Fifth, when children report economic reasons as the cause for abandoning home, these often hide deeper factors. In particular, a number of children reported that the process of leaving home was driven by the desire to earn money (i.e. 'economic reasons') but later explained that economic independence was seen as a way of gaining freedom from excessive control or abuse (by parents and others). Consequently, the ultimate cause for migration was not economic poverty but the desire to have more personal freedom. Better economic opportunities were only a means of achieving this goal.

Related to this point there is a concluding methodological issue to note. Many studies investigating why children move to the streets are conducted through quantitative one-off surveys and questionnaires. This indirectly favors the reporting of economic causes as the main factor for leaving home. A number of children reported that they presented economic poverty as the cause of street migration because this was what adults and informal education programs taught. Indeed, they indicated that they provided stereotyped and normative answers to one-off questionnaires rather than disclosing the actual reasons. In this study, the level of trust developed between child and researcher had strong implications for the reliability and depth of data gathered. Children in street situations have often lost trust in adults, and, questioning a child on personal matters, such as their departure from home, is simply not appropriate when there is not an established relationship between child and researcher. The genuine causes of migration are personal traumas, which children only reveal to people whom they trust. Economic factors are easier to report, especially when the interviewer is an unknown adult. They are more impersonal, 
usually meet the needs and preferences of the interviewer and are less likely to lead to follow up questions of a personal and/or distressing nature.

One-off surveys are poor methods of research if used on their own (Ennew and Plateau, 2004) and they are likely to produce inaccurate data on why children move to the street. Children involved in domestic physical and sexual abuse commonly feel responsible for those abuses, believing that they had somehow instilled in their perpetrators the desire to use violence against them. Thus, some informants reported feeling ashamed of revealing the deep causes for their migration. It is easier to fall back on economic poverty as the 'cause'. As Rocky, a 16 old boy, reported after four months of trust sharing with the researcher:

'I did not leave home for poverty. I left home because I was not able to inspire love and affection from my step-mother. I was ashamed to tell you before. When I say I'm on the street because my family was poor people look at me and I inspire sympathy from them. They nod saying they knew that poverty was the cause and then they give me coins. But if I say that I'm on the street because my parents were violent, people blame me saying I was not a good boy'.

As argued by Felsman (1989) in his research in Colombia, as a part of the process of constructing a new identity on the street, and of learning how to present oneself to other children, a child must learn collectively articulated experiences which include reconstructing the reasons $\mathrm{s} / \mathrm{he}$ is on the street. Research in Indonesia and North America shows that children are familiar with each others stories, and have learnt 'socially approved vocabularies' in order to express their situations and reasons for 
going onto the street (Visano, 1990; Beazley 2003). In most of the cases reported here it was observed that children initially presented their predicaments with accounts felt to be suitable for the researchers and that flagged up reasons known to promote sympathy from adults. In doing so, children themselves are contributors to the dominant narrative acting out an expected social role.

In later interviews, when children reported violence, they moved away from this ‘socially approved vocabulary'. Corporal punishment and violence against children are widespread in Bangladeshi society and are rarely seen as morally wrong. To abandon the household in order to escape corporal punishment is a form of rebellion not supported by adult society. It is not likely to inspire pity in the listener. On the contrary, it is a confession which is likely to lead adults to lecture the child and to pontificate on the important role that discipline and submission should play in a child's life. Admitting to having run away from parental/domestic discipline and punishment can expose children to further investigation by social workers and the police leading to scolding and, in extreme cases, to detention or further beating.

\section{BEYOND ECONOMIC POVERTY: SOCIAL CAPITAL AND VIOLENCE}

Having demonstrated that material poverty is, at best, only a partial explanation for child migration to the street, other factors must be analysed. In particular, the household background of children in street situations must be assessed and non economic factors brought into the analysis, so that, the understanding of the social causes of the phenomenon are considered. Recent research on children living in 
developing countries has encouraged a focus on social relationships and, in particular, on social capital (Harpham, 2003). This is because a child's perception of well-being (including mental health), is particularly influenced by variables that can be captured by the social capital framework. In this study, children were asked to consider the emotional and instrumental support received from intra- and inter-household networks, perceived levels of trust and reciprocity, the amount and quality of child care, compliance, self-esteem and the sense of belonging, the nature of role models and exposure to threats. These elements influence children's feeling of protective security and/or vulnerability. The effect of social capital, within a given community or household, upon the well-being of children has rarely been carefully evaluated. However, empirical evidence has highlighted the importance of this issue for children's perceived (Furstemberg and Hughes, 1997) and real (Furstemberg and Hughes, 1995; Runyan, Hunter et al., 1988) well being.

After considering these variables, ${ }^{17}$ children were asked to explain the living situation in their household shortly before leaving home the first time. Subsequently, their household was ranked into one of four categories: very low social capital (all or most of those variables were not fulfilled), low social capital (all or most of those variables were sometimes fulfilled), adequate social capital but vulnerable (all or most of those variables were often fulfilled, but sometimes they were not) and finally

\footnotetext{
${ }^{17}$ An explanation of these variables was given to children by using a drawing in which a child was pictured who could go and talk with an adult when in trouble (emotional support), a child who was revealing a big secret to an adult (trust), a child who was giving and receiving to/from an adult a box of sweets (reciprocity), a child who was caressed by many adults (child care), a child who was smiling thinking to himself (self esteem), and a child defended by an adult in front of a potential abuser (exposure to threats). For girl-children the pictured child was a female child.
} 
high level of social capital (all or most of those variables were constantly fulfilled) (see Table 4).

\begin{tabular}{|c|c|c|c|c|c|}
\hline \multicolumn{6}{|c|}{$\begin{array}{l}\text { Table } 4 \\
\text { Social Capital Ranking of Household (at Time of Leaving Household) According } \\
\text { to Children's Assessments } \\
\qquad \mathrm{N}=80^{18}\end{array}$} \\
\hline & $\begin{array}{l}\text { Very Low } \\
\text { Social } \\
\text { Capital } \\
\end{array}$ & $\begin{array}{c}\text { Low Social } \\
\text { Capital }\end{array}$ & $\begin{array}{l}\text { Adequate } \\
\text { Social } \\
\text { Capital } \\
\end{array}$ & $\begin{array}{l}\text { High } \\
\text { Social } \\
\text { Capital }\end{array}$ & $\begin{array}{l}\text { Don't } \\
\text { Know }\end{array}$ \\
\hline Boys & $44 \%$ & $39 \%$ & $11 \%$ & $4 \%$ & $2 \%$ \\
\hline Girls & $50 \%$ & $37 \%$ & $7 \%$ & $3 \%$ & $3 \%$ \\
\hline Total & $47 \%$ & $38 \%$ & $9 \%$ & $3.5 \%$ & $2.5 \%$ \\
\hline \multicolumn{6}{|c|}{ Source: Conticini (2004) } \\
\hline
\end{tabular}

Overall, children in street situations reported low levels of cohesion and integration with their household and this feeling of alienation was sometimes widened to include their community and/or village. Most children did not feel part of their immediate social environment even when they were there. Omar Faruq, an 11 year old boy, expressed this as follows:

'When we were at home (referring to his friends and himself) mothers and other people used to say 'you have to eat, you have to sleep, you have to go to school' and that's all. What about the love? Due to isolation and mistreatment children who don't feel that this is the right place to stay start to think what they can do for themselves and by themselves. So they leave not only their household but all the people they know'.

By contrast, when talking about the social relations between adults, children had a very different perspective, suggesting that the degree of solidarity among adult members of a community was very high and shaped by relationships of trust and

\footnotetext{
${ }^{18}$ Out of these, 24 had left home the first time within 3 months from the date of the interview, 19 reported having left home within one year from the date of the interview, 17 were on the street for more than one year but less than two years and the remaining had been on the street for more than two years.
} 
mutual help. Adults were described as having a strong sense of belonging to their community and a deep commitment to help neighbors in crisis. This apparent paradox can be explained by pointing out that, especially in social contexts which are highly constrained for children (UNICEF, 2003), the high levels of social capital enjoyed by adult members of the community can co-exist with low levels of social capital enjoyed by children (ASOARTE, AMM et al., 2002). This is because the low level of participation accorded to children largely excludes them from benefiting from shared support and mutuality. As reported by many children, when something bad happened to them such as an adult violently beating them in public, other adults do not intervene to stop the abuse because it would be considered an intrusion on the adult beating the child. Indeed, high levels of social support among community members could prevent breaking the circle of violence within the community itself. The widespread idea that communities with high levels of social capital are necessarily low in violence is not always correct (Bartlett, 2002). On the contrary, a high level of social capital in a community which constrains the lives of its children could be a setting for high levels of violence against children.

From the materials that follow, it seems highly likely that the main reasons why children leave home in Bangladesh are not economic while the percentage of children coming from economically poor and severely poor households is only 48 percent (53 percent if defined is terms of occupation and housing), the percentage coming from low and very low child-adult social capital households is 85 percent. As examined below, social and cultural factors are important in explaining child migration to the street in Bangladesh. 


\section{THE ROLE OF VIOLENCE, THE SENSE OF INJUSTICE AND THE MOVE} TO THE STREET

In recent times the Government of Bangladesh has repeatedly attempted to increase the protective environment enjoyed by children through strengthening legal provisions against child violence. ${ }^{19}$ But, as the Government admits, this emphasis on legal reforms has not translated into changed behaviours and has failed to modify cultural practices harmful to children (MoWCA, 2005). Many of the children participating in this study reported that the main cause for leaving home was the violence ${ }^{20}$ inflicted on them by parents, step-parents, relatives and other members of the community. This has an immediate, direct and negative effect on children: pain, injury and humiliation. It also has an indirect and longer-term effect: feelings of insecurity and guilt. While recognising that different children may perceive their exposure to violence and the risk of violence differently (Dwivedi, 1999), their decision to leave home was mainly driven by the desire to find a safer environment, an alternative to their household and community of birth. Many also 'learnt' that they could belong to themselves and could consider relying on their own capabilities and adaptive skills for survival. It is important to recognise that fear, anxiety, threat, uncertainty, and anger are feelings not usually produced through a single episode of

\footnotetext{
${ }^{19}$ See for instance the Nari 'O Shishu Nirjaton Doman Act 2000 on the suppression of violence against women and children and its 2003 amendment on sexual abuse and harassment.

${ }^{20}$ The use of the concept violence (aggression) toward children is very close to the concept of abuse (chronic pattern of offensive and/or harmful behaviours). Thus, the task of differentiating violence toward children from child abuse is very difficult. Indeed, abuse towards children and violence towards them are used as synonyms in this study.
} 
violence but through the use of force as a broader process of control over children in Bangladesh (Blanchet, 2001).

Acts of violence against children are classified into four main types: control (restrictions, sanctions and surveillance), emotional violence, physical violence and sexual violence (CEDAW, 1979). In the later parts of fieldwork children in our sample were asked whether they had experienced violence during the twelve-month period preceding their move to the street. In most cases this meant in their 'home' but for a few children it was in institutions and transit environments. High levels of violence were reported for both boys (Figure 1) and girls (Figure 2) ranging from menaces, isolation, imprisonment, withholding or taking of money, threatened physical harm, beatings and sexual assaults. The experience reported by Suheta, a 13 year old girl, illustrates the forms of violence that are associated with child migration. $^{21}$

'I was attending my morning class when my best classmate Rita received the order to hurry back home because her father was about to die. Rita was extremely sad and I decided to go with her to her village and stay with her and her family all the afternoon. Before the sunset I decided it was time to go back home because my parents could have been worried. When I arrived at home my father was furious because he did not know where I was and he thought something bad had happened to me. He beat me as hard as he ever did before. When I thought everything had finished he took a rope and he tied me up by the neck leaving me in the courtyard. The rope was very tight and I could not free myself, also because by that time my eyes were swollen and I was bleeding... There were many people assisting but no one said a word ... He left me tied up for two days with no food ... No, I don't think this is violence because he was worried for me. I had not informed him of my decision of going with my friend. If I had told him, he wouldn't have punished me. He did it to educate me (shikkadea) and make me understand about the dangers I could have found on the way'.

${ }^{21}$ While this is self-evidently a vicious incident it is by no means the most extreme of the accounts provided by children. 


\section{Figure 1}

Patterns of Violence Experienced

by Children in Street Situations before Moving to the Street

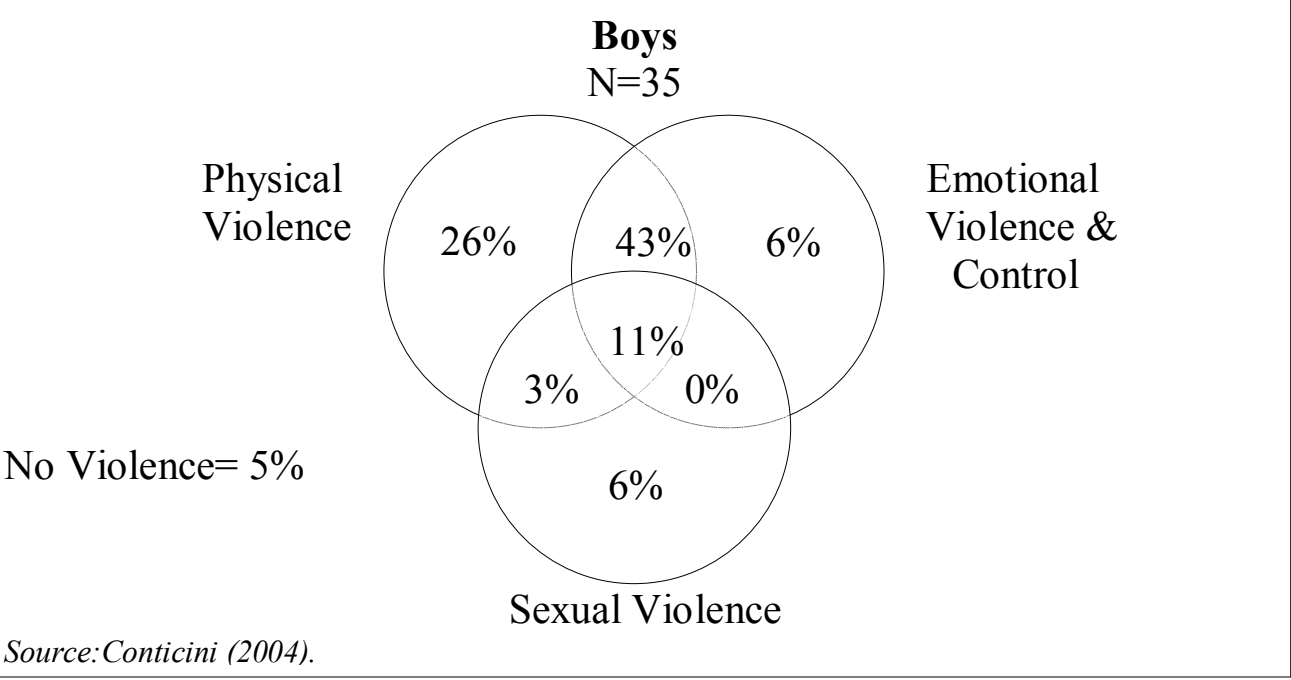

Figure 2

Patterns of Violence Experienced by Children in Street Situations before Moving to Street

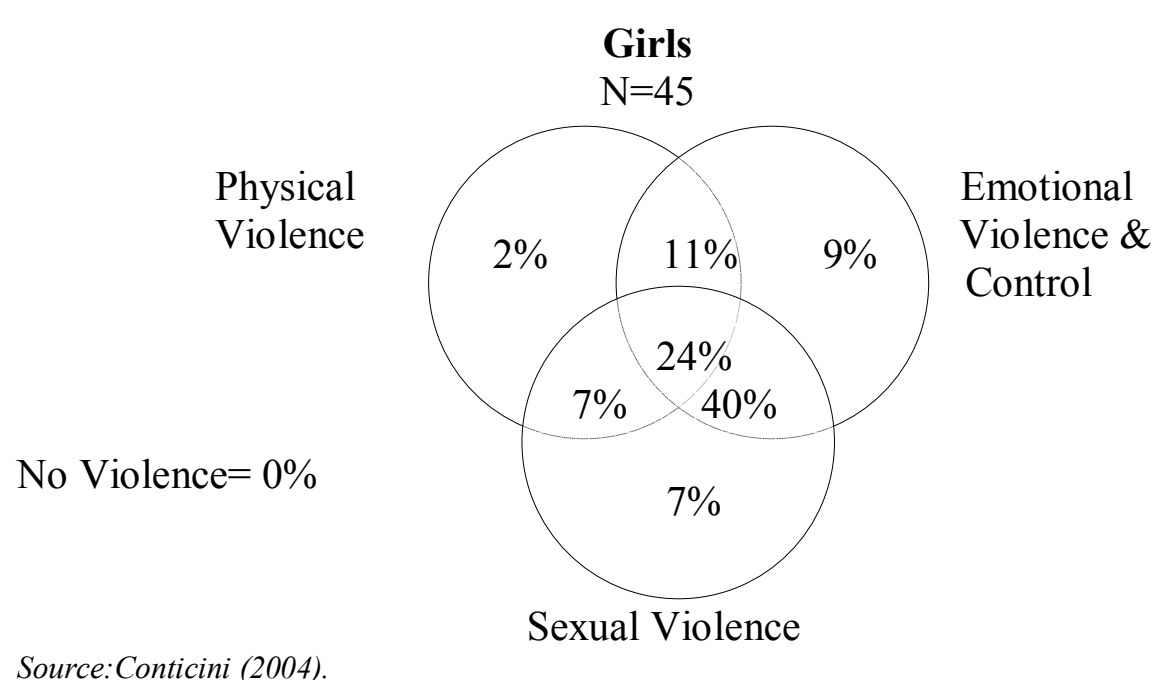


Only two of the 80 children (both boys) reported that they had not experienced violence during the year prior to their move to the street. ${ }^{22}$ Most of the children described repeated and multiple forms of violence during that period. There were profound differences in the comparative experiences of boys and girls. In particular:

(i) Boys were subjected to much higher levels of physical violence than girls (83 percent as against 44 percent).

(ii) Girls were much more likely to have experienced sexual violence than boys ( 78 percent as against 20 percent). ${ }^{23}$

(iii) Girls were twice as likely to have experienced all forms of violence as boys (24 percent as against 11 percent).

However, for both genders in most of the cases at least two types of violence were reported: physical violence and control for boys (54 percent) and sexual violence and control for girls (64 percent).

Unfortunately, this picture is supported by other recent studies on violence towards children in Bangladesh (Ghuznavi, Ghuznavi et al., 2001; Kabir, 1999; Kabir, 2002; Sarker, 2001; SCUK, 2001). Similar results have been obtained by researchers investigating the relationship between young people engaged in sex work and the sexual abuse of children in their households (Masud Ali, Mustaque Ali et al., 1997).

Children's perceptions of violence in Bangladesh are closely entwined with socialization, educational practices and bichar (fair punishment). The 'bringing up' of

\footnotetext{
${ }^{22}$ It is important for the reader to note that children were not encouraged to report violence. These reports were triangulated (by cross-checking with qualitative interviews, consistency and other data) and there was little evidence of over-reporting.

${ }^{23}$ Of the 34 girls reporting sexual violence around 28 percent cited incidents that could be categorised as rape.
} 
children, involves very highly asymmetric power relationships in Bangladesh (Blanchet, 2001; Kotalova, 1993). The idea that the use of force, physical punishment and threat is an essential component of properly bringing up children is central to childhood in the country. Indeed, it is widely believed that it is an adult's, and particularly a father's, duty to physically punish children who have erred. The use of emotional or physical violence is commonly judged by mainstream society as being in the interest of the child; it will help the child to grow up and learn to be submissive in performing his/her duties. Consequently, there is widespread acceptance of the use of punishment and violence to teach children how to behave in ways that are socially acceptable (Ghuznavi, Ghuznavi et al., 2001; Kabir, 1999).

The children who took part in this study were extremely careful in distinguishing between illegitimate violence vis-à-vis forms of punishment based on their idea of justice. Punishment only occurs when the violence is an adult reaction related to perceived child misbehavior. By contrast, onedgio bichar (unfair violence) was any adult application of violence not justified by a child's misbehaviors: it is 'unjust'. This is an important distinction because it helps to explain why some children decide to leave their household and others, under apparently similar circumstances, did not. In particular, similar acts of physical force were interpreted differently by children depending on 'why' they occurred: if there was no 'legitimate' reason for the abuse, it was seen as onedgio bichar (unfair punishment) and it could undermine a child's trust in parents or guardians. However, if the abuse was viewed as a legitimate adult reaction to a child's misbehavior it was accepted as nedgio bichar (fair punishment) and justified as a parent's duty to punish and teach a child. Children abandoning their 
household often base their decision on whether the violence they experience is just or unjust. If the behavior of adults is perceived by children as unjust, they are more likely to leave and seek security and social relationships elsewhere.

Consequently ideas about 'good' child raising, fair punishment and unjust violence are closely inter-related. The children who decided to leave their households were children who experienced high degrees of violence and especially violence that was perceived as unfair. While it is hard to bear physical, emotional and sexual violence, the biggest shock for children was the absolute collapse of the trust relationship with adults and the fear generated by the unpredictability of future unfair treatment and violence.

Although most of the interviewed children left home to escape violence or unfair punishment, for some of them the justification for migration was more complex. For this group departure appeared to be driven by low levels of self esteem and was viewed as a form of self-punishment based on a feeling of guilt. With particular reference to abusive step-parents, some children reported migration to the street not to escape abuse but to save the marriage of their natural parent. They believed that leaving home would please their natural parent and improve the quality of life within the household.

There are important differences between the genders. The number of girls in street situations was estimated to be about one quarter that for boys. This difference is not necessarily because girls experience a lower degree of violence within their households. Rather, the practice of instilling an attitude of almost complete submission in girls from an early age (Blanchet, 1996), reduces the likelihood that 
girls will confront abuse. Consequently, fewer girls leave their families to move to the street. In addition, girls usually have lower levels of knowledge about what life is like 'on the street' and, if they acquire useful knowledge, they are likely to find that sexual violence and sex work are likely to be a major component of life on the street. The 'downside' of life on the street is higher, perhaps much higher, for girls compared to boys.

\section{THE PERPETRATOR OF VIOLENCE}

Parents, stepparents, relatives, school teachers and sometimes members of the wider community, were the most commonly reported perpetrators of violence against children who move to the street. Two common patterns can be identified. The first is the marriage of young girls, and sometimes very young girls, to men who initiated them into degrading sexual practices and physical violence from which they 'ran away'. Young brides were likely to suffer from forms of violence perceived as a way of instilling submissive attitudes toward husbands. The second is abuse, by a stepparent, following the remarriage of a natural parent. This related to both stepmothers and stepfathers, the relationship between stepmothers and children appeared to be problematic in terms of lack of affection and childcare for stepchildren and for the punishing of stepchildren. The neglect and violence towards stepchildren increases with the birth of a new child between father and stepmother. By contrast, the relationships between stepfather and stepdaughter were particularly exposed to sexual abuse. 
Similarly, relationships with relatives, especially with uncles and male cousins, increased the risk of sexual violence. Also, some teachers were pinpointed as perpetrators of physical and emotional violence and control. Members of the local community were mostly indicated as perpetrators of sexual and emotional violence and control. Female adults rarely seem to impose sexual abuse on boys. All the reported cases of sexual abuse toward girls were perpetrated by male adults (Kabir, 1999 and 2002).

Evidence from the fieldwork in rural areas, suggested that abusive parents were particularly lacking in empathy, the ability to be sensitive to the needs of a child and to respond properly and at the right time to child needs. While some adults were sensitive to their birth children and stepchildren, it was generally reported that stepchildren were less prioritized and that there was greater empathy for boys rather than girls.

\section{THE CYCLE OF MIGRATION}

The migration of children from their households often appeared to be a reversible decision. While some children were committed to migration to the street, having abandoned their household, others sought transit social environments such as relatives' houses, NGO drop in centres and childcare institutions. However, when 'childcare' institutions failed to provide security and emotional support children decided to move to the street. Once on the street, some children experienced processes of adaptation that led to them committing themselves to the street. For other 
children, the street was only seen as a temporary refuge and, after the experience of street life, they were ready to return home or go to NGO drop in centers or foster families. ${ }^{24}$ While the processes of leaving the household and moving to the street can often be understood in terms of a linear model it must be recognised that 'returns' - to transit environments or households - are not uncommon (Figure 3).

\section{Figure 3 The Cycle of Child Migration to the Street}

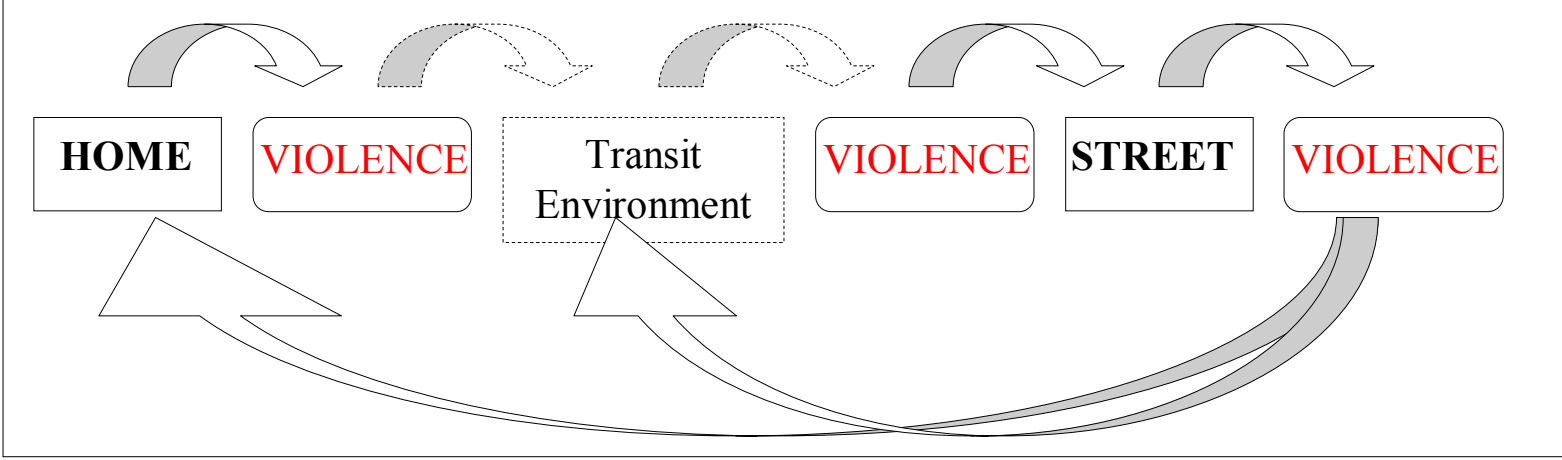

The first time that a child leaves their household he/she has to face the insecurity of relying on his or herself. This insecurity progressively reduces over time as the child gets used to taking his/her own decisions. The uncertainty of what to do once he/she has left a 'natural' household prevents many children from seeking security elsewhere and means that children tolerate a high degree of violence before they decide to leave home.

\footnotetext{
${ }^{24}$ The process of migration out of the household was sometimes reversible when the child had not lived on the street. Once experienced to street life, problems of compromised reputation make the choice of returning home difficult. Consequently, once habitualized to the street, it is easier for children to move from the street to other transit environments (like NGOs drop in centres) rather than returning home.
} 
Arguably, the child learns to consider migration or relocation as a concrete alternative to the acceptance of violence. The more the number of violent episodes experienced after abandoning their household, the greater are the number of further movements to different social environments and the lower is the degree of tolerance of abuse.

The migration of children to the street must be seen as a process, not a sudden event. It is a decision that develops over time. In a number of cases children were not able to identify a single event which led to them leaving home; on the contrary they reported thinking about leaving home a number of times before having the courage to take the decision. This appeared to be more common for girls than boys.

\section{COMPARING VIOLENCE ACROSS SOCIAL ENVIRONMENTS}

The violence experienced by children was examined in terms of its frequency and intensity. The aim of this exercise was to comparatively evaluate the street environment with other social environments such as home, transit home, school, government institutions ${ }^{25}$ and NGO drop-in centers.

In terms of frequency (how often the child suffered from violent/abusive behaviors), the street appeared to be the place where abuse was most commonly experienced, along with government institutions. These were followed by the

\footnotetext{
${ }^{25}$ These are: safe home, vagrant homes, jails and correctional centres. Despite the differences between these government institutions, children refer to them euphemistically as Shashur Bari. Literally that means 'father in law' house, but is interpreted as 'jail'. Often the living conditions within these institutions are extremely poor, with no minimum standards for protection, recovery or rehabilitation (see Donà, 2003).
} 
household, government schools, transit homes and NGO drop-in centers. By contrast, the intensity of violence (how much pain was felt and what bruises/wounds were inflicted) was reported to be worst in the original household followed by government institutions and transit homes and government schools. Streets and NGO drop-in centers were reported as places where violence was less intense.

How can these differences in the ranking of social environments for the frequency and intensity of violence be explained? Arguably, the street is understood by children to be an insecure place where protection is minimal. As a result, violence is common. However, in assessing the perceived intensity of violence, a crucial role is played by the identity of the perpetrators. On the streets the perpetrators are often unknown persons and consequently there is not a trust relationship between the offender and the child. By contrast, within household, school or transit home, the child personally knows the perpetrators. In most cases there is a pre-existing trust relationship between the child and the abuser, and this trust relationship collapses when the child suffers violence. In evaluating the intensity of violence, the children consider not only the harm and pain caused by the abuser but also the emotions of a breakdown in trust and feelings of loneliness. While living in his/her original household, a child is extremely vulnerable because he/she has not yet developed effective mechanisms of selfdefence. The main mechanism of self-defence they have is justifying abuse by parents or guardians and blaming themselves for the violence and loss of self-esteem (Hecht, 1998). By comparison, on the street, the child has already developed mechanisms of self-defence and the violence experienced does not lead to the breakdown of a 
relationship with trusted persons. By the time a child is on the street, the child already has little or no confidence in adults.

While the dominant narrative presents the street as the place where 'innocence is lost and childhood stolen' (Blanchet, 1996), the places that 'plunder childhood' (Siddiqui, 1990), are more likely to be domestic environments. The street is often the place where children seek freedom and look for the security which they did not have in their homes. On the street the children do not usually find refuge from violence, but by the time they arrive on the street, their childhood has already been stolen by abusive adults, often trusted kin, who have destroyed the child's opportunity to grow up in a secure and protective household environment. One can deplore the street for not being a safe environment for children, but those who migrate to the street, might be viewed as children only in terms of their biological age. They have already lost their innocence and they are ready to be 'adults' in their own right and live without parental/guardian supervision. For Bangladesh, the image of home as a safe environment set against the street as the place of perdition is misleading and does not recognize the role the street can play in providing significant numbers of children with an alternative to household and institutional environments that are far from secure.

\section{CONCLUSIONS}

In Bangladesh, there is a dominant narrative (Roe, 1999) that children live in street situations because of economic poverty. This account posits that children abandon 
their families because they are unable to satisfy their most basic needs within the domestic environment. Moving on to the street improves their access to income, food, clothing and other essential goods and reduces the economic strains on their households and families (by reducing their dependency ratios). This is an appealing narrative but, as we have shown, it exaggerates the role that economic poverty plays in the process of street migration. A significant minority of children in street situations in Bangladesh come from non-poor (in economic terms) households, and, when they develop a trusting relationship with a researcher, explain their 'move' in terms of other factors.

Paramount amongst these other factors is the experience of violence - excessive control, emotional violence, physical violence and sexual violence - in their domestic environment. Seventy-eight out of 80 children reported suffering violence in their household during the year before they moved to the street. For the vast majority, this violence was physical or sexual. The personal accounts of children provided harrowing evidence of extreme and cruel treatment by parents, stepparents, relatives and husbands. Abuse by stepparents was particularly common and girls on the street who were married young (and sometimes very young) reported physical and sexual abuse by husbands. In many cases relatives and neighbours knew of the abuses being imposed on children but made no effort to intervene.

Children distinguished between fair punishment (nedgio bichar), meted out by adults as part of the process of bringing children up properly and, unfair punishment (onedgio bichar), when violence is applied but it is not part of the legitimate 'bringing up' process. The qualitative evidence indicated that children accepted 
relatively high levels of 'fair' punishment but that when 'unfair' punishment occurred this led to the breakdown of trust in adults and made migration to the street both more attractive and more probable. ${ }^{26}$

We can summarise our findings and their policy implications succinctly. Children move out of households to live on the street in Bangladesh not mainly because of economic poverty (a lack of access to food, income and basic needs) but because of domestic violence and the breakdown of trust in the adult members of their household (and community). The policy implications of this finding are profound. Rather than trying to help children off the street, and assuming that economic growth and reduced income poverty will stem the flow of new children to the street, it suggests that policies to reduce street migration should focus on reducing the abuse of, and violence against children. Social policy, rather than economic policy, must take the lead. For Bangladesh society, this is an altogether less comfortable understanding of why children move to the street, and what needs to be done, than that provided by the dominant narrative.

Bangladesh has recently taken substantial efforts to extend the legal provisions protecting children from violence. As the country's contribution to the UN Global Study on Violence shows, these new legal provisions have been translated into guidelines and a national plan of action. However the new legal provisions derive

\footnotetext{
${ }^{26}$ This article could be criticized for not treating the question of the link that could exist between economic poverty and levels of stress and indeed violence within households. However, when taking into consideration existing research on the determinants of domestic/community violence towards women and children, the alleged link between economic poverty and levels of stress and indeed violence is less straight forward than what is commonly believed (see Conticini, 2004, for an extensive discussion on the issue). Additionally, in aiming to place children at the centre of this analysis, we have attempted to privilege their ways of interpreting their predicament.
} 
from a normative analysis and are not grounded in an understanding of the actual ways society interprets legitimate and illegitimate violence. The reporting of violence is still taboo for both victims and witnesses and Bangladeshi society commonly accepts physical punishment as a legitimate component of raising children. Ad hoc national, regional and district committees have been created to tackle violence against children but not yet translated into operational, community-based, mechanisms to effectively monitor and promote child protection. Promulgating new laws and designing coordination mechanisms is the easy part. Mobilising Bangladeshi society so that it re-examines what forms of violence are socially acceptable against children and creating community level institutions that will report and confront child abuse is the challenge that faces policymakers and social activists in the country. 


\section{References}

Agnelli, S. (1986). Street Children: A Growing Urban Tragedy. London: George Weidenfeld \& Nicholson.

Ahmed, S. and A. M. Adeeb. (1998). Methods and Techniques of Street Education and Substance Abuse Prevention Among Street Children. Dhaka: AparajeyoBangladesh \& Childhope-Asia.

Alexandrescu, G. (1996). 'Programme Note: Street Children in Bucharest'. Childhood, Global Journal of Child Research 3(2):267-270.

Aptekar, L. (1988). Street Children of Cali. Durham and London: Duke University Press.

ARISE. (2001). Baseline Survey of Street Children in Six Divisional Cities of Bangladesh, Edited by A. R. f. I. S. C. Environment. Dhaka: Department of Social Services, Ministry of Social Welfare, Government of Bangladesh.

ASOARTE, AMM, GEAC, and MAFUM. (2002). 'Exploring Youth and Community Relations in Cali, Colombia'. Environment and Urbanization 14(2):149-156.

Baker, R. (2000). 'The Importance of Being Connected: Perspectives from Nepali Street Children'. Cultural Survival Quarterly 24(2): 49-51.

Bartlett, S. (2002). 'Building Better Cities with Children and Youth'. Environment and Urbanization 14(2):3-9.

Bartlett, S., R. Hart, D. Satterthwaite, X. De La Barra, and A. Missair. (1999). Cities for Children: Children's Rights, Poverty and Urban Management. London: United Nations Children's Found-Earthscan.

Beazley, H. (2003). 'The Construction and Protection of Individual and Collective Identities by Street Children in Indonesia'. Children, Youth and Environments, 13(1). Available online at http://cye.colorado.edu.

Black, M. (1993). Street and Working Children, Edited by I. G. S. Report. Florence: United Nations Children's Found.

Blanc, S. C. (1994). Urban Children in Distress. Luxembourg: Gordon and Breach Publishers.

Blanchet, T. (1996). Lost Innocence, Stolen Childhoods. Dhaka: The University Press Limited.

Blanchet, T. (2001). Constructions of Masculinites and Violence against Women. Dhaka: CARE Bangladesh.

Bradbury, B., S. P. Jenkins, and J. Micklewright. (2000). Child Poverty Dynamics in Seven Nations, vol. Innocenti Working Paper No.78, Edited by I. R. Centre. Florence: United Nations Children's Found.

Brandon, D. and K. Wells. (1980). The Survivors: A Study of Homeless young Newcomers to London and The Responses Made to Them. London: Routledge \& Kegan Paul.

Bruijn, M. E. and H. J. W. Van Dijk. (1999). 'Insecurity and Pastoral Development in the Sahel'. Development and Change 30(1):115-139.

BSAF. (1998). Cases Studies of 10 Tokai Children. Dhaka: Bangladeshi Shishu Adikar Forum. 
Bustamante, D. (1999). 'Family Structure Problems, Child Mistreatment, Street Children and Drug Use.' Pp. 27-35 in Prevention of Street Migration, edited by C. F. S. Children. London: CSC.

CEDAW. (1979). Convention on the Elimination of All Forms of Discriminations Against Women: UN General Assembly.

Chambers, R. and G. Conway. (1992). Sustainable Rural Livelihoods: Practical Concepts for the 21st Century, vol. DP 296, Edited by U. o. Sussex. London: IDS.

Chawla, L. (2002). Growing Up in an Urbanising World. Paris: Earthscan-UNESCO.

Connolly, M. and J. Ennew. (1996). 'Children Out of Place'. Childhood, Global Journal of Child Research 3(2):131-145.

Conticini, A. (2004). 'We are the Kings: The Children of Dhaka's Streets.' Ph.D. Thesis, Institute for Development of Policy and Management, University of Manchester, Manchester.

CSC. (2001). Violence Against Children Within the Family. London: Consortium for Street Children.

Dallape, F. (1996). 'Urban Children, a Challenge and an Opportunity'. Childhood, Global Journal of Child Research 3(2):283-294.

Donà, G. (2003). Overview of the Conditions of Children Outside Parental Care in Institutions and Communities. Dhaka: United Nations Children's Found.

Dwivedi, R. (1999). 'Displacement, Risks and Resistance: Local Perceptions and Actions in the Sardar Sarovar'. Development and Change 30(1):43-78.

E/CN.4/2004/68 (2004). Concept paper for the Secretary-General's Study on Violence Against Children. Available at www.ohchr.org/english/bodies/crc/study.htm

Ellis, F. (1998). 'Survey Article: Household Strategies and Rural Livelihood Diversification', Journal of Development Studies, 35(1): 1-38.

Ennew, J. and B. Milne. (1996). Methods of Research With Street and Working Children: an Annotated Bibliography. Stockholm: Radda Barnen Publishing.

Ennew, J and D. Plateau (2004). How to Research the Physical and Emotional Punishment of Children. Resource Handbook. Bankgog: Save the Children.

Felsman, J. K. (1989), 'Risk and Resiliency in Childhood: The Lives of Street Children.' Pp. 56-80, in The Child in Our Times: Studies in the Development of Resiliency, edited by Dugan,T and Coles, R. New York: Brunner and Mazel.

Furstemberg, F. and M. Hughes. (1995). 'Social Capital and Successful Development among at-risk Youth'. Journal of Marriage and the Family 57(3):580-592.

Furstemberg, F. and M. Hughes. (1997). 'The Influence of Neighbourhoods on Children's Development: a Theoretical perspective and a research agenda.' in Neighbourhood Poverty: Poverty Implications in Studying Neighbourhoods, vol. 2, edited by J. Brooks-Gunn, D. Duncan, and J. Aber. NY: Russell Sage Foundation.

Ghuznavi, R., F. Ghuznavi, and S. R. Khan. (2001). Child Rights: Reality and Challenges, Edited by S. A. Sangjog. Dhaka: DFID-British Council.

Gordon, D., S. Nandy, C. Pantazis, S. Pemberton, and P. Townsend. (2003). Child Poverty in the Developing World. Bristol: The Policy Press. 
Green, D. (1998). Hidden Lives: Voices of Children in Latin America and the Caribbean. London: Cassell.

Harpham, T. (2003). Measuring Social Capital of Children, vol. Working Paper N.4: Young Lives.

Hasina, S. (1989). Ora Tokai Keno. Dhaka: United Nations Children's Found.

Hecht, T. (1998). At Home in the Street: Street Children of Northeast Brasil: Cambridge University Press.

Hrdy, B. (1992). 'Fitness Tradeoffs in the History and the Evolution of Delegated Mothering'. Ethology and Sociobiology 13:409-442.

Hulme, D. and A. Shepherd. (2003). 'Conceptualizing Chronic Poverty'. World Development 31(3):403-423.

Hulme, D., A. Shepherd and K. Moore. (2001). 'Chronic Poverty: Meanings and Analytical Frameworks'. CPRC Working Paper 2, Manchester: IDPM, University of Manchester.

Kabir, R. (1999). Adolescent Girls in Bangladesh. Dhaka: United Nations Children's Found.

Kabir, R. (2002). Adolescent Boys in Bangladesh. Dhaka: United Nations Children's Found.

Kotalova, J. (1993). Belonging to Others: Cultural Construction of Womenhood in a Village in Bangladesh. Uppsala: Uppsala University.

Lucchini, R. (1996a). 'The Street and its Image'. Childhood, Global Journal of Child Research 3(2):235-246.

Lucchini, R. (1996b). 'Theory, Method and Triangulation in the Study of Street Children'. Childhood, Global Journal of Child Research 3(2).

Lugalla, J. and J. Mbwambo (1999). Street Children and Street Life in Urban Tanzania. Oxford: Joint Editors and Blackwell Publishers Ltd.

Masud Ali, A. K. M., A. K. M. Mustaque Ali, and R. Sarkar. (1997). Misplaced Childhood: A Short Study on the Street Child Prostitutes in Dhaka City. Dhaka: INCIDIN.

Monteiro, J., M. Campos, et al. (1998). 'An Autophotographic study of Poverty, Collective Orientation and Identity Among Street Children'. Journal of School Psychology 138(3): 403-406.

Moser, C. (1998). 'The Asset Vulnerability Framework: Reassessing Urban Poverty Reduction Strategies'. World Development 26(1): 1-19.MoWCA. (2005). People's Republic of Bangladesh Contribution to the Global Study on Violence Against Children. Ministry of Women and Children Affairs. Dhaka.

Minujin, A., J. Vandemoortele, and E. Delamonica. (2002). 'Economic Growth, Poverty and Children'. Environment and Urbanization 14(2):23-44.

De Oliveira, W., M. Baizerman, et al. (1992). 'Street Children in Brazil and their Helpers: Comparative Views on Aspirations and the Future'. International Social Work 35: 163-176.

Olwig, K. F. and N. N. Sørensen. (2001). 'Mobile Livelihoods: Live and Work in Aglobalising World.' London and New York: Routledge. 
Panter-Brick, C. (2002). 'Street Children, Human Rights and Public Health'. Annual Review of Anthropology 31.

Panter-Brick, C. and T. M. Smith. (2000). Abandoned Children. Cambridge: Cambridge University Press.

Parazelli, M. (2002). La Rue Attractive: Parcours et Pratiques Identitaires des Jeunes de la Rue. Sainte-Foy, Presses de L'Université du Québec.

Pare, M. (2003). 'Why have Street Children Disappeared? The Role of International Human Rights Law in Protecting Vulnerable Groups'. The International Journal of Children's Rights 11(1):1-32.

Peacock, R. (1994). 'Street Children'. Africa Insight 24(2):138-143.

Ravallion, M. and B. Sen. (1996). 'When Method Matters: Monitoring Poverty in Bangladesh'. Economic Development and Cultural Change 44(4):761-792.

Roe, E. M. (1999). Except Africa. Remaking Development, Rethinking Power. London: New Brunswick \& London Transaction Publishers.

Runyan, D., W. Hunter, R. Socolar, and L. Amaya-Jackson. (1988). 'Children who Prospers in Unfavourable environments: the relationship to social capital'. Paediatrics 101:12-18.

Sarker, A. H. (2001). Juvenile Delinquency: Dhaka City Experience. Dhaka: Human Nursery For Development.

Scheper-Hughes, N. and D. Hoffman. (1998). 'Brazilian Apartheid: Street Kids and the Struggle for Urban Space.' in Small Wars: the Cultural Politic of Childhood, edited by N. Scheper-Hughes and C. Sargent. Berkeley: University of California Press.

Scoones, I. (1998). 'Sustainable Rural Livelihoods: A Framework for Analysis', IDS

Working Paper 72. Brighton: Institute of Development Studies.

SCUK. (2001). Our Children in Jail: Year Book on the State of Juvenile Justice and Violence against Children in Bangladesh. Dhaka: Save The Children UK.

Sen, A. (1999). Development As Freedom. Oxford: Oxford University Press.

Sen, B. (2000). Fighting Human Poverty: Bangladesh Human Development Report 2000. Dhaka: BIDS.

Sen, B. and S. Begum. (2004). Identifying and Targeting the Extreme Poor: A Methodology for Rural Bangladesh. Dhaka: First Draft of Unpublished Article for Chronic Poverty Research Centre, IDPM, University of Manchester.

Siddiqui, K. (1990). Social Formation in Dhaka City. Dhaka: The University Press Limited.

Solito, L. (1994). 'Where are the Children In the City Agenda?' in Urban Children in Distress, edited by S. C. Blanc. Florence: United Nations Children's Found.

Stepputat, F. and N. N. Sørensen. (2001). 'The Rise and Fall of 'Internally Displaced People' in the Central Peruvian Andes'. Development and Change 32(4):769791.

Tacoli, C. (1999). Urban Governance, Partnership and Poverty: IIED.

UNDP. (2000). Bangladesh Human Development Report 2000. Dhaka: UNDP.

UNICEF. (2002). We the Children: Meeting the Promises of the World Summit for Children. NY: United Nations Children's Found. 
UNICEF. (2003). Give Us Voice, We Know what We Want: Children's and Young People's Perceptions on the Implementation of the Convention on the Rights of the Child in Bangladesh. Dhaka: United Nations Children's Found.

Veale, A. (1992). 'Towards a Conceptualisation of Street Children: The Case from Sudan and Ireland'. Tròcaire Development Review: 107-121.

Visano, L. (1990). 'The Socialization of Street Children: The Development and Transformation of Identities', in Adler.P. \& Adler.P. (eds), Sociological Studies of Child Development, Vol 3: 139-161.

White, S. (2002). 'From the Politic of Poverty to the Politics of Identity? Child Rights and Working Children in Bangladesh'. Journal of Development Studies 14(3):725-735.

Yaqub, S. (2003). 'Chronic Poverty: Scrutinising Patterns, Correlates and Explorations'. CPRC Working Paper 31. Manchester: IDPM, University of Manchester.

Zhang, H. X. (1999). 'Female Migration and Urban Labour Markets in Tianjin'. Development and Change 30(1):21-41. 
Alessandro Conticini is a former post-doctoral fellow at the Institute for Development Policy and Management (IDPM) at the University of Manchester, and affiliated researcher to the Chronic Poverty Research Centre. Currently is the head of Child Protection within UNICEF Ethiopia. His research interests centre upon children in poverty issues, lifecourse and intergenerational transmission of poverty in urban areas. His research and working experiences include children in war and conflict zones, refugee children, HIV/AIDS orphans and street living and working children primarily in South Asia and Africa.

David Hulme is Professor of Development Studies and Director of the Chronic Poverty Research Centre at the Institute for Development Policy and Management at the University of Manchester and Joint Director of the ESRC's Global Poverty Research Group. His research interests are poverty analysis, poverty reduction, rural development, microfinance, role of NGOs and natural resource management. South Asia has been the focus of his research but he has also worked in the Pacific and East Africa 